\title{
Ethical passivity between maximal and minimal meanings
}

\section{Pasividad ética entre eficiencia máxima y mínima}

\section{Passividade ética entre a eficiência máxima e mínima}

Fecha de recepción: 7 de enero de 2016
Fecha de evaluación: 7 de marzo de 2016
Fecha de aceptación: 16 de marzo de 2016

Publicación en línea: 17 de mayo de 2016

Manuel Losada Sierra*

Hernando Barrios Tao**

DOI: http://dx.doi.org/10.18359/rlbi.1674

Cómo citar:

Losada Sierra, M. y Barrios Tao, H. (2016). Ethical passivity between maximal and minimal meanings. Revista Latinoamericana de Bioética, 16(2), 70-81. DOI: http://dx.doi.org/10.18359/rlbi.1674.

Artículo de reflexión.

* Ph.D. in Philosophy, Lecturer and Researcher at Faculty of Education and Humanities, Universidad Militar Nueva Granada. Email manuel.losada@unimilitar.edu.co. ORCID: http://orcid. org/0000-0002-3681-8475. Bogotá, Colombia

* Ph.D. in Theology, Lecturer and Researcher at Faculty of Education and Humanities Universidad Militar Nueva Granada. Email: hernando.barrios@unimilitar.edu.co. ORCID: http://orcid. org/0000-0002-8999-0586. Bogotá, Colombia 


\begin{abstract}
This paper is a critical review of the most relevant studies about the Levinasian concept of passivity. The purpose is to follow the way in which Levinas's scholars have dealt with the following aspects: the relation between ethical passivity and the possibility of effective ethical agency, the origin of passivity, and the validity of ethical passivity in the public sphere. As a starting point for future research, I finally argue that the best way to read Levinas's passive ethics is through the dynamism between maximums and minimums present within it. This means that without sacrificing the omni comprehensive view of divine revelation and Jewish tradition, Levinas presents ethics as rationally understandable by everyone and philosophically defensible. Despite being biblically based, Levinas does not appeal to authority in supporting his view, he is confident in arguing rationally. This account could place Levinas in the way of public ethics, which consists in an ethos shared by all members of democratic societies. These minimums of justice could be the way to universalize Levinas's ethics.
\end{abstract}

Keywords: Levinas, ethics, passivity, maximums, minimums.

\title{
Resumen
}

El presente artículo es una revisión crítica de los más importantes estudios sobre el concepto levinasiano de pasividad. El propósito del mismo es seguir el camino a través del cual estos estudios han tratado los siguientes aspectos: la relación entre pasividad ética y la posibilidad real de una efectiva agencia ética, el origen de la pasividad y la validez de la pasividad ética en la esfera pública. Finalmente planteo, como principio para una subsecuente investigación, que el mejor camino para leer el concepto de pasividad en Levinas es a través del dinamismo entre máximos y mínimos presentes en él. Esto significa que sin sacrificar la visión omnicomprensiva de la revelación divina y la tradición judía, Levinas presenta la ética como racionalmente entendible por todos y defendible filosóficamente. A pesar de estar basada en la Biblia, Levinas no recurre a ninguna autoridad dogmática para justificar su visión. Él está confiado en argumentar racionalmente. Esta perspectiva puede poner a Levinas en la línea de la ética civil que consiste en un ethos compartido por todos los miembros de las sociedades democráticas. Lo mínimos de justicia puede ser el camino para universalizar la ética de Levinas.

Palabras clave: Levinas, ética, pasividad, máximos, mínimos.

\section{Resumo}

Este artigo é uma revisão crítica dos estudos mais importantes sobre o conceito Levinasiano de passividade. O objetivo do mesmo é seguir o caminho através do qual estes estudos têm abordado as seguintes questões: a relação entre passividade ética e a possibilidade real de uma eficaz agência de ética, a origem de passividade e a validade da passividade ética na esfera pública. Finalmente esboço como princípio para uma pesquisa posterior, que a melhor maneira de ler o conceito de passividade em Levinas é através do dinamismo entre máximos e mínimos presentes nele. Isto significa que, sem sacrificar a visão abrangente da revelação divina e da tradição judaica, Levinas apresenta a ética como racionalmente compreensível por todos e filosoficamente defensável. Apesar de ser baseada na Bíblia, Levinas não recorre a nenhuma autoridade dogmática para justificar sua visão. Ele está confiado em argumentar racionalmente. Essa perspectiva pode colocar a Levinas na linha da ética civil, que consiste em um ethos compartilhado por todos os membros das sociedades democráticas. O mínimo de justiça pode ser o caminho para universalizar a ética de Levinas.

Palavras-chave: Levinas, ética, passividade, máximos, mínimos. 


\section{Introducción}

According to an established tradition, only free acts and their consequences are relevant from an ethical standpoint. Only a free human being can aspire to a better life and look for the ways to accomplish it. This timeless aspiration to happiness goes through history looking for the best system that unveils the "secret" of a good life. From the Aristotelian Thomistic tradition to the modern and contemporary, and irrespective of their different historical and philosophical backgrounds, philosophers are confident in the capacity of humans to actively find the best solution for the challenging question about how to live as rational beings in a shared world. In this regard, the coexistence of different beliefs and ways of conceiving the ideal of a good life are the main characteristics of contemporary societies. For this reason, contemporary ethical and political reflection has a great interest in the common substrate of values that integrates the different world-views regardless of cultural differences.

Emmanuel Levinas appears on the philosophical scene challenging the conception of ethical agency as freedom of choice, introducing radical passivity as the way to authentically live as humans, and pointing out an ethic with a distinctly religious language. For Levinas, the term "subject" must be understood in the sense of the passive participle: subject as subjected or dependent on someone (the Other). Subjectivity is not subject in the grammatical sense: it is not the "I" that accompanies all my actions. The first-person pronoun can only refer to the subject when it is conjugated in the accusative. The passivity of the subject is not the nonexercise of freedom, as it is voluntary. It is passivity prior to any freedom.

Secondary literature on Levinas's thinking has highlighted some concrete problems. Questions arise about how passivity can be the source of actions and ethical decision-making: how we can put aside the care of ourselves and be bound or subjected to respond for the other; thus, what is the ethical relevance of an action not chosen but imposed? (Hofmeyr, 2009a, p. 1).

Related to these concerns, I wonder if it is possible that this perspective of ethics, defined by Levinas as religion and rooted in a subject that appears always responding to a previous call from an immemorial and anarchic time, can be of relevance in democratic, religiously pluralistic and culturally diverse societies. In these societies, religious monism as an instrument of moral control has lost influence, and law and civil ethics are the most important regulators of behaviour. Ethics of liberal societies is premised on consensus among citizens about the minimum level of justice that allows them to live peacefully where there are diverse ways to comprehend the ideal of a good life. After all, we live in a world in which we inevitably have to deal with discourse, adaptation, comprehension, and history.

This review will trace the origin of ethical passivity, and from there it will ask whether Levinas's account of ethics can be universalised beyond Jewish culture, 
or whether it is valid only in the Jewish believer's intimate sphere. Is this ethics socially effective and morally valid? What can be the meaning of this ethics for people's everyday life? How can this ethics operate in human-to-human contact? The concept of chosenness of the Jewish people and the continuous references to biblical categories in Levinas's reflection and, on the other hand, the necessity of a shared ethos to live in pluralistic and multicultural societies makes the question sensible and meaningful.

In the existent literature, this review will develop three aspects: 1. ethical passivity and the possibility of an effective ethical agency; 2. the origin of passivity, and 3. the validity of ethical passivity in the public sphere.

\section{Passivity and ethical agency}

Deficiencies in Levinas's account of passivity as a basis for an effective ethical agency upon have been pointed out by Lingis (2009) and Peperzak (2009). Lingis argues that the responsibility assigned to the subject to respond for the other, for its needs and actions, cannot be the basis for an ethical action. If the subject has to respond for everyone and everything, this makes an effective answer impossible. The subject does not have all the resources to cover all the necessities of everyone else. Furthermore, the recognition of the other is because in it appears the face of the absolute Other, of God, and this puts the other in the uncertainty of its situatedness because there are infinite demands posed by an infinite number of others. Finally, according to Lingis, Levinas's lack of recognition of the things of the world and nature which the subject appropriates and enjoys, and that require care and protection is incomprehensible. In this sense, things of the world and animals, for example, could be manipulated ignoring that they have to be protected.

Lingis's stance on thinking the encounter with the other in absolute empirical terms is problematic because Levinas, as we know, tones down the radicalism of the responsibility when the social order appears in the face of the other (Levinas 1969 , p. 212; 1991, p. 157). In this sense, Bernasconi argues that behind Levinas's contention of passivity are the conditions of possibility of ethics; but, on the other hand, recognises that this encounter can happen in real life (Bernasconi 2002). In Bernasconi's assertion is reflected Levinas's proposal of thinking about ethics as the reference level from which the real world has to be criticized (Levinas 1969, p. 80).

Distinguishing in Levinas's works between the passivity of the world of enjoyment that appears in Totality and Infinity and the absolute passivity before the call of the other in Otherwise than Being, Peperzak shows how welcome and recognition of the other is impossible in the world of enjoyment to which the subject remains addicted (Peperzak, 2009). This is the relative passivity of the addiction to the world of consumption. Therefore, it is necessary to open up space to an absolute passivity in which the subject welcomes and responds for the other. However, it is unclear, for 
Peperzak, how the subject can take care of the other without taking care of itself, in such a way that it is not the passivity of the rock or the machine. Peperzak is in favour of accepting the need of the subject's improvement to respond appropriately to the requirements of the other.

Unlike Lingis, Peperzak contends that Levinas's ethical language does not correspond to empirical experiences but is pre o meta-logic. It describes a situation of responsibility that precedes every ethics (Peperzak, 1993, p. 223). Despite the differences of the radicalism of the critics, both, Lingis and Peperzak, agree on considering the impossibility of ethical action from the subject's passivity.

Against this framing, some scholars accept the possibility of basing ethical agency as a horizon of meaning of concrete ethical actions rather than considering passivity in empirical terms (Bernasconi 2002; Morgan 2011; Zeillinger 2009). In this line of thinking, Morgan's historical and phenomenological analysis conceives Levinas's concept of passivity as part of the twentieth-century debate about the subject's autonomy, individuality, and freedom (Morgan 2011, p. 115-19). According to Morgan, Levinas places his account of subject in the debate about the primacy of the self, and the criticism of the individual's capacity for self-knowledge and autonomy. In this respect, Bernasconi states that Levinas takes ethics out of the traditional frame of philosophy, having three targets in mind: overcoming Hobbesian egoism, responding to the Heideggerian concern for own existence and rejecting the traditional conceptions of ethics rooted in freedom (2002, p. 239). The final contention of both Morgan' and Bernasconi' is that Levinas's purpose with the concept of passivity is to clarify what the subject must be like for the everyday experience to be meaningful. The same conclusion is drawn by Zeillinger affirming that Levinas merely wants to account for the possibility of sacrifice for the other and not "that one should sacrifice oneself" (2009, p. 107). In other words, Levinas's use of ethical language can be understood as a search for the conditions of comprehension of ethics, and responds to the meaning of ethical concrete situations.

\section{Roots of passivity}

The exploration of the concept of passivity in phenomenological sources has followed in the footsteps of Jean Wahl (Hofmeyr 2009b) and Maurice Merleau-Ponty (Bergo 2009). According to Hofmeyr, Wahl conceives the relation between the self and the other in a double movement, trans-ascendant and trans-descendant. The trans-ascendant is a movement towards the other propelled by an infinite desire. This is the encounter with the other that puts the idea of infinity into the self, affecting its egoistical preoccupations. The trans-descendant, on the other hand, is a downward movement into the subject itself. While the first one paradoxically leaves the subject in the immanence, the trans-descendant movement allows the subject to discover something that has not been there before the encounter with the other: the idea of infinity which 
is prior to autonomy and leads us to find something that has always already been there, the other-in-the-same. In being the subject subjected to the other-in-the-same, ethical agency lies in "inner force that incapacitates freedom, understood as involuntarily egoistical" (Hofmeyr, 2009, p. 28). Therefore, passivity stems from this intertwining between upward and downward movements in which the subject discovers itself inevitably tied to the other to whom and for whom the subject must be responsible.

The exploration of the phenomenological roots of Levinas's concept of passivity takes a different path with Bettina Bergo. She performs an analysis comparing Levinas and Merleau-Ponty's accounts of passivity, showing common interests and divergences. According to

Bergo, both Levinas and Merleau-Ponty draw on "Edmund Husserl's work on passive synthesis, from the consciousness of internal time to association, and attempt to outline the conditions under which passivity can be approached", fully aware that a thematization of passivity will reinsert it into intentional consciousness, thereby re-establishing its dualism with activity (Bergo, 2009, p. 31). The condition of phenomenological priority of passivity is recognised by Bergo as do almost all readers of Levinas. This means the other-in-thesame is "undergone passively before it is represented" (2009, p. 31).

Going a step further, Bergo incorporates the symbolism of Merleau-Ponty's dreams to weaken the standard readings of Levinas's status of the world and immanence in later phenomenology. The objective world, meaning everyday thinking and activities, never makes sense in Otherwise than Being. Hyperbolic concepts like substitution could be best understood as a modality of perception "possibly akin to falling sleep or to Merleau-Ponty's sense of dreaming, in which the other becomes all, in which the posited 'I', the body-subject, belongs to a field crossed by other fields or other "others" (Bergo, 2009, p. 51). Passivity is rooted in intersubjectivity that presupposes bodily existence and flesh. According to Bergo, passivity in Levinas is sensuous because it pursues intersubjectivity, and this pre-supposes the third party, not solely the face-to-face relation with the other.

Despite what Hofmeyr's and Bergo's studies suggest, it is essential for this research to trace the religious route to passivity (Anckaert, 2009; Fagenblat, 2010; Topolsky, 2009). In this sense, Fagenblat affirms that the best way to understand Levinas is by tracing the biblical and rabbinical roots Levinas uses for philosophical purposes; that is, without religious intentions but rather by secularizing them. By interpreting Levinas as a hermeneutical thinker, Fagenblat wants to save Levinas from the charge of dogmatism and discover the value of Judaism for phenomenological inquiry. Levinas would philosophize from the Jewish textual tradition while constructing a phenomenological interpretation of Judaism (Fagenblat, 2010). 
To demonstrate, Fagenblat points out that Levinas's major philosophical works, Totality and Infinity and Otherwise than Being or Beyond Essence, are "midrashically determined from beginning to end", and specifically an ethical response to evil (Fagenblat, 2010, p. xxiii). According to Fagenblat, passivity comes to light in Otherwise than Being and is one characteristic among several that demonstrates the depth of the change undergone by Levinas in his second great work. In Totality and Infinity, ethics is grounded in a created world from chaos in the image of God, in which a separated subject responds to the face of the other; however, in Otherwise than Being, the emphasis is on the moral creature subjected to the other and bound to respond for it (Fagenblat, 2010, pp. 101- 106). In this sense, while in Totality and Infinity Levinas uses a metaphysical theology, in Otherwise than Being he uses a nonmetaphysical secularized theology.

Anckaert (2009), for his part, analyses Levinas's Talmudic commentary And God Created Woman to argue that the concept of creation in this text has a twofold meaning, linguistically expressed by the duplication of the verb "to create" in Genesis 2:22: creation ex-nichilo, and creation of the man and of the woman. In the first creation, man is put under God's gaze in total exposure and in the second, being human is found to have an unconditional responsibility. This responsibility stems from the fact that the human being receives the whole world created after it as a mandate, therefore, making it responsible for something that it has not done. While Fagenblat sees passivity as a characteristic born in Otherwise than Being and, therefore, outside of the concept of creation in the image of God, Anckaert states that passivity stems from the twofold meaning of creation in Genesis.

Understanding passivity from the concept of creation as Anckaert does is problematic.

Before him, some Levinas's readers have also expressed the importance of the concept of creation in Levinas's account of ethics (Gaviria Alvarez, 1974; Margaria 2005; Petrosino, 1995). Nevertheless, I considerer that this concept to Levinas would have some negative consequences: the ontologization of God, considered as first cause; exclusion of the separation and self-sufficiency inherent to human existence (which would be a divine poiesis); and ontologization of the man-God bond, displaced from the salvific plane to the cosmic one.

Close to Fagenblat, Topolsky (2009) argues that Levinas's work can be understood by taking seriously the philosophical and Talmudic sources of his thinking to understand a typical Jewish philosophy. By coining the expression "Judeosophy", Topolsky characterises the way in which Levinas integrates biblical and rabbinic teachings in his philosophical thinking. Levinas's philosophy cannot be adequately understood if any of the sources of his thinking is excluded. It is not Jerusalem or Athens but both, Jerusalem and Athens. In this sense, Richard Cohen contends that the unique difference between Levinas's philosophical and religious discourses lies in the audience to which they are 
addressed and not in the message that Levinas is transmitting (Cohen, 2010, p. 200). According to Topolsky, to understand the concept of passivity and ethics, in general, it is necessary to considerer the biblical concepts of face, "here I am" and God. The concept of face, panim, refers us to the concept of the hostage. Similarly, the concept of response, hineni, translated as "here I am", helps us to grasp responsibility prior to freedom, a freedom not chosen but imposed. Finally, in this relationship, the trace of God is experienced as an infinite responsibility, for which, according to Levinas, "I carry the weight of the world" (Banon, Levinas \& Ricoeur, 1998, p. 25).

Topolsky's reading of Levinas is a very interesting one, but her view requires a further explanation of the consequences of the concepts of face, response and God. My contention is that passivity stems from the concept of revelation that is an act of speech and is fundamentally an order or mandate. Jewish revelation is based on prescription. The attitude of the person receiving revelation is obedience (Levinas, 1996, p. 206), and this obedience, according to Levinas, comes from a love of neighbour, a love obeyed, lacking self-indulgence. This love is responsibility for the neighbour, the taking upon oneself of the destiny of the other, or fraternity. An effective, ethical action from responsibility before freedom is the consequence of the obedience to revelation. Therefore, passivity is neither Lingis's lack of resources nor Peperzak's lack of care for itself, but passivity non-satisfied, passivity as a formal level of ethical action and non-satisfied because as Levinas says "the other concerns me in all his material misery" (Levinas, 2001, p. 52).

Levinas recognises the problem of justifying revelation from reason rather than solely from faith. Is it possible to break the closed circle of totality and its correlative, the self-sufficient reason? If at least this break were thinkable, "the main part of the problem would be solved", according to Levinas (1996, p. 205). He wonders if there might be another way, different to rationality, through which we base our possibilities to comprehend the world. Levinas is confident in showing the richness and sufficiency of a passive subject who does not relate to the other through cognitive intentionality but through the richness of "the explosion of the "the more within the less' which Descartes called the Idea of Infinity, and demonstrates a psyche which is more alert than that of intentionality, or a knowledge adequate to its object" (1996, p. 208). For Levinas, a passive ethics, obedient to the divine commandment and responsible for the other, shows a greater richness of meaning than the closed rationality of the subject. After all, ethics is not lucidity but responsibility.

Unlike Fagenblat, it is my contention that Levinas's ethics is showing an absolute, which, nonetheless, does not prevent him from attempting a reasonable presentation without appealing to any revealed authority. By showing that Levinas does not take into account the concepts of peoplehood and law, Fagenblat wants to save Levinas from the accusation of dogmatism (Fagenblat, 2011). I consider, 
however, that Levinas's account of law is essential to comprehend ethical passivity. This means, in my view, the presence in his ethical opus of omnicomprehensive maximums of Jewish culture and faith and, at the same time, minimums with a vocation of universalisation.

\section{Secular or religious ethics?}

Opening up the question of religion, we run into the possibility of viewing Levinas's ethics as a dogmatic account of Judaic particularism of revelation, or, on the other hand, the possibility of universalisation through the rational account of shared ethos beyond Levinas's Jewish-cultural background. In the first possibility, we find Dominique Janicaud (2000) who believes that Levinas uses the language of the phenomenology to turn theologically towards the invisible, so his ethics is valid only for those who share the same religious tradition. The rationale is subordinated to the religious, to the revelation of the invisible face for which the subject is responsible prior to any personal decision. According to Janicaud, this approach necessarily refers to an authority beyond reason and, therefore, non-philosophical. The same suspicion about the dogmatic character of Levinas's philosophy is shared by Gillian Rose (1993), Judith Butler (2000) and Alain Badiou (2002) who contend that it is an expression of a dogmatism that has its source in revelation. With a more positive attitude towards Levinas, Ajzenstar (2001) shares Fagenblat and Topolsky's contentions about the essential Jewish nature of Levinas's work, but acknowledges the difficulties in philosophically justifying Levinasian ethics, and, therefore, its limited usefulness in the social sphere. Levinas's account of ethics will be useful in the private codes sphere of the religious person, but without pretensions of universality.

Opportunities to open channels of communication with other "theologies" from the Levinasian perspective of ethics have been considered by other scholars (Cohen, 2010, Urbano, 2012). By reading Levinasian monotheism ethically and not epistemologically a dialogue is possible between religions, according to Cohen (2010). These lines of communication between people, more than simply between ideas, would discover values of interhuman kindness and fairness that enable interchange and interhuman understanding. According to Cohen, the demand to put the other first and the call to justice for everyone are two concepts that can contribute to overcoming the clashes among religions. It is the consequence to start human relations from the saying and not from the said as said (2010, pp. 224-54). Cohen's claim is coherent with his reading of Levinas's philosophy, where, as stated above, he does not find essential differences between Levinas's religious and philosophical writings. In this line of thinking, Urbano (2012) analyses the possibility of an interfaith dialogue on the basis of Levinas's proposal. Recognizing that Levinas does not give concrete guidelines for dialogue but conditions of possibility, Urbano states that from Levinas can be drawn an ethical encounter more than an objective discourse. Both, Cohen and Urbano, place Levinas in dialogue with 
other religions to overcome differences and reach understandings between them. The question, nonetheless, remains in terms of possibilities of universalisation beyond Judaism to build democratic societies beyond "theologies".

\section{Conclusion}

Concerning the validity of Levinas's religious perspective in the public sphere, I claim that the best way to read his ethical passivity is through the dynamism between maximums and minimums present within it. This means that without sacrificing the omnicomprehensive view of divine revelation and Jewish tradition, Levinas presents ethics as rationally understandable by everyone and philosophically defensible. Despite being biblically based, Levinas does not appeal to authority in supporting his view; he is confident in arguing rationally. This account could place Levinas in the way of civil ethics, which consists in an ethos shared by all members of democratic societies. These minimums of justice could be the way to universalise Levinas's ethics.

This reading has several consequences. Firstly, justice, for Levinas, has a religious and philosophical dimension and, probably against the same Levinas, philosophical and religious writings should be read together to properly appreciate ethics. Then, Levinas's account of ethics can be universalised and can be socially effective. Finally, ethical agency could be understood as an expression of a way of humanization that opens up with the responsibility for the other and for the others who are always present from the beginning in the ethical relation. This responsibility is comprehensible beyond biblical revelation and opens ways of communication between different modes to understand the Aristotelian ideal of good life.

The idea of ethical maximum and minimum is developed mainly by Spaniard philosopher Adela Cortina and for Professor Michael Walzer at the American Institute for Advanced Study. Cortinas's question is

How it is possible -which remains the big question- to design offers of moral philosophy, politics and religion that make possible the reconciliation of the demands of ethical universalism with the rich plurality of ethical maximum. How it is possible to think and live adequately universal demands for justice and invitations to happiness, projects with meaning for life and death, rooted in cultures, traditions and diverse histories. (Cortina, 2000, p. 11).

According to Cortina, it is necessary to build a secular ethics from traditions, belie$\mathrm{fs}$, and economic conditions of members of society. In short, pluralism of worldviews requires a consensus about the minimum ethics of a democratic and multicultural society. Walzer (1994) appeals to minimal and maximal meanings of morality and says "we can standardly give thin and thick accounts of them, and the two accounts are appropriate to different contexts, serve different purposes" (p. 2). While the thin meaning appears in specific times and places and is based on common understanding of its meaning, the thick meaning 
is shared in the same language, history, religion and politics.

Levinas's account of passive ethics is shaped as an answer to divine revelation that provides values that are philosophically comprehensible and, therefore, universalizable. Through Cortina and Walzer, it is possible to show how this ethics can be read based on the dynamism of maximums and minimums, overcoming the criticism of dogmatism that has been levelled at it. Thus, Levinas provides a frame for an ethics valid in civil societies beyond Jewish particularisms, and in this sense, Levinas appears as both a Jewish and a universalizing thinker. Furthermore, values that come from revelation provide the scenario for the ethical action in Levinasian philosophy. In fact, responsibility as Levinas says "is a matter eventually, of nourishing him (the other), of clothing him. It is exactly of biblical assertion: Feed the hungry clothe the naked, give drink to the thirsty, give shelter to the shelterless" (2001, p. 52).

\section{References}

Ajzenstar, O. (2001). Driven Back to the Text: the PremodernSources ofLevinas's Postmodernism. Pittsburgh: Duquesne University Press.

Anckaert, L. (2009). L' tre Entre les Lettres: Creation and Passivity in 'And God Created Woman'. In B. Hofmeyr (Ed.), Radical Passivity: Rethinking Ethical Agency in Levinas (pp. 143-54). Dordrecht: Springer.

Badiou, A. (2002). Ethics: An Essay on the Understanding of Evil. London : Verso.

Banon, D., Levinas, E. \& Ricoeur, P. (1998). Emmanuel Levinas: Philosophe Et
Pédagogue. Paris: Editions du Nadir de l'Alliance israélite universelle.

Bergo, B. (2009). Radical Passivity in Levinas and Merleau-Ponty (Lectures of 1954). In B. Hofmeyr (Ed.), Radical Passivity: Rethinking Ethical Agency in Levinas (pp. 31-52). Dordrecht: Springer.

Bernasconi, R. (2002). What is the Question to Which Substitution is the Answer. In S. Critchley \& R. Bernasconi (Eds.), The Cambridge Companion to Levinas (pp. 243-51). Cambridge: Cambridge University Press.

Butler, J. (2000). Ethical Ambivalence. In M. Garber, B. Hanssen \& R L. Walkowitz (Eds.), The turn to Ethics (pp. 15-28). New York: Routledge.

Cortina, A. (2000). Ética Mínima: Introducción a la Filosofía Práctica (6th. Ed.). Madrid: Tecnos.

Cohen, R. (2010). Levinasian Meditations: Ethics, Philosophy, and Religion. Pittsburgh: Duquesne University Press.

Gaviria Álvarez, O. (1974). Lidée de création chez Levinas: une archéologie du sens. Revue Philosophique de Louvain, Quatrième série, 72(15), 509-38. Retrieved from http:// www.persee.fr/web/revues/home/prescript/article/phlou_00353841_1974_ num_72_15_5802

Fagenblat, M. (2010). A Covenant of Creatures: Levinas's Philosophy of Judaism, Stanford: Stanford University Press.

Fagenblat, M. (2011). Response. AJS Review, 35(1), 115-124.

Hofmeyr, B. (2009a). Editor's Introduction: Passivity as Necessary Condition for Ethical Agency? In B. Hofmeyr (Ed.), Radical Passivity: Rethinking Ethical Agency in Levinas (pp. 111). Dordrecht: Springer.

Hofmeyr, B. (2009b). Radical Passivity: Ethical Problem or Solution? In B. Ho- 
fmeyr (Ed.), Radical Passivity: Rethinking Ethical Agency in Levinas (pp. 15-30). Dordrecht: Springer.

Janicaud, D., Courtine, J.F., Chrétien, J.L., Marion, J.L. et al. (2000). Phenomenology and the "Theological Turn: The French debate. New York: Fordham University Press.

Kosky, J. (2001). Levinas and the Philosophy of Religion. Bloomington: Indiana University Press.

Levinas, E. (1969). Totality and Infinity: An Essay on Exteriority. Pittsburgh: Duquesne University Press.

Levinas, E. (1985). Ethics and Infinity: Conversations with Philippe Nemo. Pittsburgh: Duquesne University Press.

Levinas, E. (1991). Otherwise than Being or Beyond Essence. Dordrecht: Kluwer Academic Publishers.

Levinas, E. (1994a). Nine Talmudic Readings. Bloomington: Indiana University Press.

Levinas, E. (1994b). In the Time of the Nations. Bloomington: Indiana University Press.

Levinas, E. (1996). Revelation in Jewish Tradition. In S. Hand (Ed.), The Levinas Reader (pp. 190-210). Oxford: Blackwell Publishers.

Levinas, E. (2001). Interview with Francois Poirié. In J. Robins (Ed.), Is it Righteous to Be? (pp. 23-83). Stanford: Stanford University Press.

Lingis, A. (2009). The Fundamental Ethical Experience. In B. Hofmeyr (Ed.), Radical Passivity: Rethinking Ethical Agency in Levinas (pp. 81-93). Dordrecht: Springer.

Margaria, L. (2005). Passivo elo Attivo: L'enigma dell'umano tra Levinas e Ricoeur. Roma: Armando Editore.
Morgan, M. (2011). The Cambridge Introduction to Emmanuel Levinas. Cambridge: Cambridge University Press.

Peperzak, A. (1993). To the Other: An Introduction to the Philosophy of Emmanuel Levinas. West Lafayette: Purdue University Press.

Peperzak, A. (2009). Sincerely yours: Towards a Phenomenology of Me. In B. Hofmeyr (Ed.), Radical Passivity: Rethinking Ethical Agency in Levinas (pp. 55-66). Dordrecht: Springer.

Petrosino, S. (1995). Lidée de création dans l'œuvre de Lévinas. In La Différence Comme Non-Indifférence: Éthique et Altérité chez Emmanuel Lévinas (pp. 97-107). Paris: Éditions Kimé.

Purcell, M. (2006). Levinas and Theology. Cambridge: Cambridge University Press.

Schroeder, B., Benso, S. (2008). Levinas and the Ancients. Bloomington: Indiana University Press.

Rose, G. (1993). Judaism and Modernity: Philosophical Essays. Oxford: Blackwell.

Topolsky, A. (2009). Listening to the Language of the Other. In B. Hofmeyr (Ed.), Radical Passivity: Rethinking Ethical Agency in Levinas (pp. 111-30). Dordrecht: Springer,

Urbano, R. (2012). Levinas and interfaith dialogue. The Heythrop Journal, LIII, 148-161.

Walzer, M. (1994). Thick and Thin: Moral Argument at Home and Abroad. Notre Dame: University of Notre Dame Press.

Zeillinger, P. (2009). Radical Passivity as the (Only) Basis for Effective Ethical Action:

Reading the 'Passage to the Third' in Otherwise than Being. In B. Hofmeyr (Ed.), Radical Passivity: Rethinking Ethical Agency in Levinas (pp. 95-108). Dordrecht: Springer. 